AperTO - Archivio Istituzionale Open Access dell'Università di Torino

THE ITALIAN PLAN 2013-2016 TO DEVELOP THE OFFICINAL PLANTS SECTOR

This is a pre print version of the following article:

Original Citation:

Availability:

This version is available http://hdl.handle.net/2318/147915

since 2020-04-08T10:41:50Z

Published version:

DOI:10.4172/2167-0412.1000153

Terms of use:

Open Access

Anyone can freely access the full text of works made available as "Open Access". Works made available under a Creative Commons license can be used according to the terms and conditions of said license. Use of all other works requires consent of the right holder (author or publisher) if not exempted from copyright protection by the applicable law. 
UNIVERSITÀ DEGLI STUDI DI TORINO 
This is an author version of the contribution published on:

Questa è la versione dell'autore dell'opera:

[Med Aromat Plants, Vol 3, Issue 2 , 2014, DOI 10.4172/21670412.1000153]

The definitive version is available at:

La versione definitiva è disponibile alla URL:

[http://www.omicsgroup.org/journals/medicinal-aromatic-plants.php] 
Cover letter

Corresponding author: Cinzia Barbieri

e-mail cinzia.barbieri@unito.it

Tel. +39011 6703826

I agree to publication.

Please, take care of the following:

!!! Notes. Where I have to insert them? They are, now, after References.

I am sorry, but I did not found an example in MED\&Aromatic ...

List of changes to reviewers comments

1 - words mispelled / I check them and I hope they are right now

2 - page 3 - I checked

3 - I changed

4 - I changed

References: I saw the online Instruction for authors

CHANGES to first version submitted (before revision)

I eliminate corresponding author and e-mail after affiliation after the title because I I see a your published article as example.

I modify key words.

I modify the end of Introduction and added Note 2.

I modify the of end of the second paragraph.

I modify Aknowledgments. 


\title{
The Italian Plan 2013-2016 to develop the officinal plants sector
}

\section{Cinzia Barbieri ${ }^{1}$}

${ }^{1}$ University of Torino, Via Verdi 8, 10124 Torino, Italy

\begin{abstract}
The aim of this note is to inform, but to 'not strictly insiders', the interventions that will be planned in Italy to develop and support officinal plants sector (Piano di settore delle Piante officinali 2013-2016, Plan for the officinal plants sector 2013-2016). This note is structured as follows: the introduction outlines the context within was developed the Plan, while the following paragraphs are, respectively, dedicated to the description of the officinal plants sector and analysis of it. In the Conclusions the synthesis of the findings of the Plan. This first analysis will follow the study of interventions aimed to develop the examined sector in other European countries.
\end{abstract}

Key words: Herb, Officinal plants, Competitiveness, Development, Research 


\section{Introduction}

Statistical data show the positive trend of the consumption of officinal plants ${ }^{1}$ and a renewed interest of public institutions in Italy [1,2]. In the last decade this led to the development of the processing and marketing, but did not have equal effect on the crop. In fact, about $70 \%$ of the raw material is imported. Why? It is the price the determining factor. The domestic production, which recognizes high-quality, does not compete with the price of similar production of the Eastern Europe, the Mediterranean basin or even, of the Central and South America. The above observations motivate the choice of planning, at the national level, interventions to develop the sector and, also, this short note. The Plan is the outcome of a previous work of preparation, started in 2011. It is due to underline that, currently, the Plan is still not implemented ${ }^{2}$.

\section{The officinal plants sector in Italy}

Production. In Italy (2010), the cultivation of MAPs involves 2,938 farms and a surface of 7,191 hectares. The medium size is approximately 2.5 hectares, and increased from 2000 to 2010 (the surface increased more than 200\%, while the number of farms decreased of $29 \%$ ) [2,3]. It is to underline that more than 2,900 hectares are 'organic' (41\% of the total surface with officinal plants, 2010) [2]. The 67\% of the primary production is in three regions: Piemonte, Emilia-Romagna and Marche [2]. The last Italian Agricultural Census 2010, shows the increasing of surfaces and farms with MAPs in Piemonte and Valle d'Aosta (Northwest of Italy), Trentino-Alto Adige and Friuli (Northeast), Emilia-Romagna and Marche (Central) regions [2].

Exchanges [2]. In the year 2011, Italy imported approximately 161 million tons equals to 999 million euros of officinal plants and their derivatives (22.8\% odoriferous substances for non-food industry, $30.5 \%$ odoriferous substances for the food industry), more than $50 \%$ from non-EU countries; the exports involve 82 million tons equals to 413 million euros (27.0\% vegetable saps and extracts, essential oils $19.3 \%, 15.6 \%$ odoriferous substances for the food and beverage industry ), for two thirds directed to EU countries. Both imports and exports increased in the period 2000-2010. The supply-chain can be described as follows [2,3].

- Farms (300-400, estimated data) specialized or not. Specialized farms are localized in traditional areas of production: Piemonte Region (Municipalities of Moretta, Pancalieri e Savigliano, 'Mint of Pancalieri)'; the areas between Puglia and Basilicata regions, and in the Sicily Region. 
- Integrated farms, also called 'a ciclo chiuso' (closed cycle) because produce and process and market (herbs, essential oils, etc.). They are approximately one hundred.

- Wholesale. The most significant companies are about fifteen, with a market share of 80\%. Many wholesalers, including companies of Germany and France, are also processors.

- Industrial companies that produce semi-finished and/or products for final consumption (food, cosmetics, pharmaceuticals, etc...), are about 2,000 (estimated data).

- Retailers. Include: health food stores $(4,500)$, pharmacies $(17,927)$, drugstores $(2,398)$, GDO corner (292), SPA, farmer markets, and other (restaurants, fitness centers, etc.).

In general, the examined sector show: a) strenghts related to high quality of domestic products, and to the increasing of consumption and export; b) weaknesses due to the lack of legislation, the poor organization of producers and the small size of farms with high production costs $[1,2,3]$.

\section{The Plan for the officinal plants sector}

The Plan covers the years 2013-2016 and is divided in two parts. The first part focuses on the description and analysis of the sector. It is the results of the research work carried out by ISMEA [2]. In the second part are described the objectives to develop the sector. The main objective is to increase the competitiveness of the sector with actions at the national, regional and local level. In general, it is underlined that: a) the primary production requires intervention; b) the National Law 6 January 1931, No. 99, that regulates the cultivation and collection of officinal plant, and regional laws have to be updated and harmonized $[1,2,5,6]$; c) the knowledge of the sector has to be improved; it is necessary to collect statistical data trough ad hoc surveys, and the updating of the statistical classification of products/sectors of activities that do not reflect the current commercial reality. Then are detailed more specific objectives (called 'principals') that would allow: a) farmers to access to EU funding regulated by the Common Agricultural Policy (CAP), with interventions similar to those of the flower sector; b) include the Plan actions in the Rural Development Programmes of the EU [6]. It proposes measures to improve domestic production (i.e. trademarks, certification), national actions of communication and promotion and improvement of the distribution system. This last aspect is of importance at the level of primary production and provides the creation of 'Centers of primary processing' (economies of scale), and the formation of Associations, Cooperatives and Consortia of producers. The key issue is to encourage 
the entry of young people into the sector, especially primary, and support exportoriented firms. Moreover, the Plan expected to create a 'National Observatory on prices and statistics' at the Ministry of Agricultural, Food and Forest Policies.

Finally, the Plan gives space to the research activities. In general, it is necessary to coordinate public and private research through the establishment of 'Centers of excellence' that provide support and services, i.e. logistics, to producers. The lines of research include: development of certified seed production to reduce the import and to better check the quality of raw materials; manufacture of machines for production and collection (containing the cost of production); preservation of germplasm, natural and indigenous; development of plant protection products suitable for 'natural productions' that shall not contain chemical residues.

The financing of actions: there are no direct funding but only indirect, arising from the measures of the Rural Development Programmes (regional in Italy) that use EU funds $[1,4,6]$.

\section{Conclusion}

The Plan starts from the description and analysis of the officinal sector in Italy. It underlines that the increase in the consumption of 'everything that is natural' favored the increasing of production of herbs (the quantities produced and exported are increased). The weakest part of the chain is still the primary production. There are some large farms but, generally, they have small size, with a negative effect on the cost of production. Than the Plan focuses on the objectives and actions to improve the competitiveness of domestic production: a) modernize and harmonize the legislation (national, regional) is highlighted; b) enhance the knowledge of the sector (there is a lack of statistical data); c) support the development of Associations of agricultural producers to aggregate the supply, reduce processing costs and, thus, the cost of the domestic raw material.

Aknowledgments. The Author is grateful to the Dr. Antonella Finizia (ISMEA, Roma) for her collaboration. 


\section{References}

1. Barbieri C (2013) Medicinal and aromatic plants legislation in the European Union, Italy and several of its regions Natural Product Research: Formerly Natural Product Letters 27:17 1576-1582.

2. ISMEA Osservatorio Economico del settore delle piante officinali edited by A. Finizia (2013) Piante officinali in Italia: un'istantanea della filiera e dei rapporti tra $i$ diversi operatori, Roma, Italy.

3. Barbieri C (2001) Indagine conoscitiva sul mercato delle piante officinali e dei loro derivati: con particolare riferimento alle problematiche delle specie coltivate in Valle Cannobina. INTERREG II Programma Operativo plurifondo concernente la frontiera esterna Italia-Svizzera, II Fase di Programmazione, Misura 2.1, AZIONE a) Ricerche di mercato per definire la quantità e qualità delle produzioni tipiche e locali, Comunità Montana Valle Cannobina, Regione Piemonte, Torino, Italy.

4. Council Regulation (EC) No. 1698/2005 (2005) on rural development.

5. Legge Nazionale (1931) del 6 gennaio 1931, No. 99 Disciplina della coltivazione, raccolta e commercio delle piante officinali (National Law of 6 January 1931, No. 99, Medicinal plants disciplines of growing, harvesting, and marketing).

6. Ministero della Salute, Ministero delle Politiche Agricole Alimentari e Forestali, ISMEA (2013) Piano di settore delle Piante officinali 2013-2016. Draft. Roma, Italy.

\section{Notes}

(1) In Italy MAPs are called 'officinal plants' or PMAC (Piante medicinali, aromatiche e da condimento).

(2) As required by the Decreto Legislativo n. 22818 of May 2001, Orientamento $e$ modernizzazione del settore agricolo (Guidance and modernization of the agricultural sector), in the 2011 was set up a Technical Committee (Tavolo tecnico), composed of representatives appointed by public bodies and organizations operating in the sector of herbs at the national level (production, processing, trading and distribution). Special Working Groups wre also set up (the 'Steering Coordination Committee', and four other groups 'Legislation National and EU policies', 'Certification and Quality', 'Research and Experimentation', 'Economic Observatory'), and were appointed experts belonging to these groups. The Plan was presented during the 'Workshop on officinal plants', July 2013, Rome, Italy. The Technical Committee and the 
Working groups were formally established in 2013

(http://www.politicheagricole.it/flex/cm/pages/ServeBLOB.php/L/IT/IDPagina/ 7064). 